Izvirni znanstveni članek/Original scientific article

\title{
Kakovost problemov, obravnavanih pri problemskem učenju: ocena študentov zdravstvene nege
}

\author{
The quality of problems used in problem-based learning: the nursing students' \\ assessment
}

Vida Gönc, Mateja Lorber, Jasmina Nerat

\begin{abstract}
Ključne besede: evalvacija; zdravstvena nega; problemi; študenti
\end{abstract}

Key words: evaluation; nursing; problems; students

viš. pred. mag. Vida Gönc, viš. med. ses., univ. dipl. org.

\section{Kontaktni e-naslov/ \\ Correspondence e-mail: \\ vida.goenc@um.si}

viš. pred. dr. Mateja Lorber, viš med. ses., univ. dipl. org.

pred. Jasmina Nerat, viš. med. ses., univ. dipl. org.

Vse/All: Univerza v Mariboru, Fakulteta za zdravstvene vede, Žitna ulica 15, 2000 Maribor

\section{IZVLEČEK}

Uvod: Z vpeljavo problemskega učenja se je spremenil kontekst učenja. Z uporabo kakovostnih problemov $\mathrm{v}$ okviru problemskega učenja se spodbuja kritično mišljenje, skupinske interakcije, uporaba teorije v praksi. Namen raziskave je bil ugotoviti oceno študentov zdravstvene nege glede kakovosti problemov, obravnavanih $\mathrm{v}$ okviru problemskega učenja.

Metode: Uporabljeno je bilo kvantitativno neeksperimentalno raziskovanje, podatki so bili zbrani s tehniko anketiranja. V raziskavi je sodelovalo 196 študentov zdravstvene nege. Za obdelavo podatkov je bila uporabljena deskriptivna statistika, t-test in korelacijska analiza. Statistično značilnost smo preverjali na ravni $5 \%$ tveganja.

Rezultati: Povprečne ocene vseh trditev, ki so se nanašale na oceno kakovosti problemov, obravnavanih v okviru problemskega učenja, so bile visoke $(\bar{x}>4$ od 5 ). Glede na način študija zdravstvene nege (redni, izredni študij) $(t=-1,333, p=0,558)$ in $\operatorname{spol}(t=0,236, p=0,354)$ ne prihaja do razlik $v$ oceni kakovosti obravnavanih problemov. Ugotovljene so bile razlike $\mathrm{v}$ oceni kakovosti obravnavanih problemov glede na zaposlenost $\mathrm{v}$ zdravstvu $(t=2,109, p=0,04)$ ter pozitivna šibka povezanost $(r=0,190, p=0,002)$ med starostjo in oceno kakovosti obravnavanih problemov.

Diskusija in zaključek: Raziskava pokaže visoko oceno kakovosti problemov, obravnavanih v okviru problemskega učenja, s čimer se pri študentih spodbuja samousmerjeno učenje, povečuje zanimanje za učno enoto in izboljšujejo motivacija za delo, komunikacijske spretnosti ter kritično razmišljanje. Nadaljnje raziskave bi bilo smiselno usmeriti $\mathrm{v}$ spremljanje vpliva problemskega učenja na učne izide ter uvedbo problemskega učenja $\mathrm{v}$ vse učne enote $\mathrm{v}$ okviru študija zdravstvene nege.

\footnotetext{
ABSTRACT

Introduction: With problem-based learning the context of learning has changed. The use of problem-based learning promotes critical thinking, group interaction, and the use of theory in practice. The purpose of the research was to determine the nursing students' assessment regarding the quality of problems used in the context of problem-based learning.

Methods: The study employed methods of quantitative non-experimental research and a survey data collection. A total of 169 nursing students participated in the study. The data were processed by descriptive statistics, t-test and correlation analysis. The statistical significance was tested at a $5 \%$ risk level.

Results: The average of all items which were related to the assessment of the quality of problems in the context of the problem-based learning was high $(\bar{x}>4$ out of 5$)$. Depending on the mode of study $(t=-1.333, p=0.558)$ and gender $(t=0.236, p=0.354)$, there is no difference in the quality of self-assessment of problems within the problem-based learning. The findings of the study show that there is a statistically significant difference in self-assessment of the quality of problems in the context of the problem-based learning with regard to the employment in nursing $(t=2.109, p=0.04)$ and that there is a weak positive correlation $(r=0.190, p=0.002)$ between the age and the self-assessment of the quality of problems in the present problem-based learning. Discussion and conclusion: Research results reveal high average values of the quality of problems used in the problem-based learning, which result in positive encouragement of students for self-directed learning, increased interest in a learning unit, improved motivation, better communication skills and critical thinking. Further research would be needed to explore the impact of problem-based learning on learning outcomes and the introduction of problem-based learning in all learning units of the nursing study programme.
} 


\section{Uvod}

Problemsko učenje (angl. Problem-based learning PBL) je bilo prvič uporabljeno v poznih šestdesetih letih dvajsetega stoletja pri izobraževanju zdravnikov v Kanadi. Od takrat se uporablja $\mathrm{v}$ različnih dodiplomskih in podiplomskih programih kot aktivna metoda učenja ( $\mathrm{Al}$ Kloub, et al., 2014), ki temelji na uporabi strukturiranih problemov za učenje (Hmelo Silver \& Barrows, 2015). $\mathrm{Z}$ uporabo problemskega učenja se spreminja kontekst učenja, saj spodbuja kritično mišljenje, skupinske interakcije in uporabo teorije v praksi (Kong, et al., 2014; Martyn, et al., 2014) ter prevzemanje odgovornosti za lastno učenje (Hmelo Silver \& Barrows, 2006). Kritično mišljenje je treba razumeti kot spretnost, ki se je učimo $\mathrm{z}$ razvojem logičnega in doslednega razmišljanja (Borglin, 2012) in ki vključuje tako kognitivne kot vedenjske komponente (Paul, 2012) ter velja za enega od najpomembnejših konceptov v izobraževanju (AziziFini, et al., 2015). Nekateri avtorji (Hwang \& Kim, 2006; Schmidt, et al., 2009; Niemer, et al., 2010) navajajo, da je pri učnih enotah, ki v svoj učni načrt vključujejo problemsko učenje, učinkovitost učenja večja. Zaradi problemskega učenja imajo študenti in diplomanti boljše sposobnosti medsebojnega sodelovanja, bolje povezujejo teorijo $\mathrm{s}$ prakso, manjši je osip študentov med študijem, študenti študij prej zaključijo in kakovost učnih programov ocenjujejo višje v primerjavi s študenti, ki so študirali na tradicionalen način. Problemsko učenje združuje več kognitivnih procesov, ki spodbujajo pridobivanje znanja in razumevanje naučenih vsebin (Loyens, et al., 2012). Obravnavanje kompleksnih problemov, ki se uporabljajo pri problemskem učenju, vključuje številne funkcije, ki spodbujajo visoko stopnjo kognitivnih procesov (Loyens, 2014).

Metoda učenja se izvaja $\mathrm{v}$ manjših skupinah, da izkoristimo predhodno znanje študentov in povečamo pomembnost uporabljenih konceptov. Učitelj pri problemskem učenju je spodbujevalec, mentor ali vodnik, ki pomaga študentu pri učenju ter usmerja $\mathrm{k}$ reševanju problemov $\mathrm{s}$ samostojnim učenjem, skupinskim delom, analizo literature in iskanjem informacij po internetu (Hmelo Silver \& Barrows, 2006; Hmelo Silver \& Barrows, 2008). Vloga učitelja se manjša $s$ sposobnostjo študentovega vključevanja samorefleksije, razmišljanja, usmerjanja ustreznih vprašanj in komentarjev pri reševanju problemov $\mathrm{v}$ okviru problemskega učenja (Lu, et al., 2010).

$\mathrm{Za}$ uspešno problemsko učenje so ključnega pomena visoko kakovostni oblikovani problemi (Munshi, et al., 2008), ki imajo elemente odprtosti, privlačnosti, ustreznosti in razumljivosti (Kim, et al., 2006). Le-ti morajo ustrezati ravni študentovega predhodnega znanja, spodbujati samostojno učenje ter motivirati za študij (Azer, 2007). Zato je, kot navaja Chan (2008), pomembno zavedanje, da učitelji na uspešnost študentov vplivajo s svojim strokovnim znanjem in osebnostnimi lastnostmi. Saj kot ugotavljajo Thammasitboon in sodelavci (2007), problemsko učenje bistveno izboljša komunikacijo s pacientom, ter kot navajata Sangestani in Mahnaz (2013), tudi kritično mišljenje, samostojno učenje, samoocenjevanje, timsko delo ter aplikacijo v prakso.

Problem, uporabljen pri problemskem učenju, predstavlja organizacijski okvir za pridobivanje novega strukturiranega znanja (Jones, 2008). Različni avtorji (Schmidt, et al., 2007; Loyens, et al., 2012) navajajo, da je pri oblikovanju problema treba upoštevati štiri faze problemskega učenja. Študenti v prvi fazi aktivirajo predznanje in $\mathrm{z}$ razpravljanjem $\mathrm{v}$ skupini predlagajo možne razlage ali rešitve. Če je njihovo znanje pomanjkljivo, se oblikujejo učna vprašanja, ki vodijo v študentovo nadaljnje samostojno učenje. Druga faza je torej obdobje samostojnega učenja, ko študenti proučujejo literaturo, povezano $\mathrm{z}$ učnimi vprašanji. Tretja faza je faza poročanja, ko se posamezne ugotovitve predstavijo skupini. V četrti fazi pa se na osnovi diskusije in kritične analize oblikujejo rešitve problema. Dobro oblikovani problemi problemskega učenja spodbujajo razmišljanje, so strukturirani, odprti, večajo zanimanje za predmet, so realni in skladni s študentovimi izkušnjami (Hmelo Silver \& Eberbach, 2012), študentom zagotavljajo povratne informacije o njihovem znanju (Kapur \& Kinzer, 2007) ter so osnova za interaktivno reševanje ob podpori usposobljenega učitelja (Walker \& Leary, 2009). AlHaqwi (2014) poudarja, da na uspešnost pri problemskem učenju vplivajo poleg izbire problemov tudi strokovno znanje učitelja in njegove organizacijske ter komunikacijske sposobnosti.

\section{Namen in cilji}

Namen raziskave je bil ugotoviti mnenje študentov zdravstvene nege o kakovosti problemov, obravnavanih v okviru problemskega učenju. Predvidevali smo, da obstajajo razlike $\mathrm{v}$ oceni kakovosti obravnavanih primerov glede na demografske značilnosti študentov. Zanimalo nas je, $\mathrm{v}$ kolikšni meri obstajajo razlike $\mathrm{v}$ oceni kakovosti obravnavanih problemov glede na spol, starost, način študija in zaposlenost študentov v zdravstveni negi. $V$ ta namen smo si zastavili naslednji hipotezi:

H1: V oceni kakovosti primerov, obravnavanih pri problemskem učenju, prihaja do statistično pomembnih razlik glede na spol, način študija in zaposlenost študentov v zdravstvu.

$\mathrm{H} 2$ : Med starostjo študentov in oceno kakovosti problemov, obravnavanih pri problemskem učenju, obstaja pozitivna povezanost.

\section{Metode}

Za izvedbo raziskave smo uporabili deskriptivno metodo dela in kvantitativno neeksperimentalno metodologijo raziskovanja. 


\section{Opis instrumenta}

Uporabljen je bil vprašalnik z 18 trditvami, ki so se nanašale na oceno kakovosti problemov, obravnavanih $\mathrm{v}$ okviru problemskega učenja. K tem trditvam smo dodali še eno, ki se je nanašala na splošno oceno kakovosti obravnavanih problemov, ter demografske podatke (spol, starost, način študija, zaposlenost $\mathrm{v}$ zdravstvu). Za proučevanje kakovosti problemov, obravnavanih $\mathrm{v}$ okviru problemskega učenja, smo uporabili že uporabljen vprašalnik (Munshi, et al., 2008). Z njim smo ocenjevali kakovost obravnavanih problemov $\mathrm{Z}$ vidika šestih kategorij: spodbujanje razmišljanja in analize, spodbujanje samousmerjenega učenja, usmerjanje $\mathrm{k}$ študiju predvidene vsebine, večanje zanimanja za učno enoto, povezanost $\mathrm{z}$ bodočim poklicem in ustreznost stopnji predhodnega znanja. Vsaka izmed proučevanih kategorij je vsebovala tri trditve, do katerih so se anketirani opredeljevali s stopnjo strinjanja po petstopenjski Likertovi lestvici (1 - "nikakor se ne strinjam «, 2 - "ne strinjam se", 3 - »nisem opredeljen/a«, 4 - "strinjam se« in 5 "popolnoma se strinjam«). Koeficient zanesljivosti (Cronbach $\alpha$ ) za uporabljeni vprašalnik je znašal 0,948.

\section{Opis vzorca}

Raziskavo smo izvedli med študenti zdravstvene nege Univerze v Mariboru na Fakulteti za zdravstvene vede. Anketirali smo študente 1. in 2. letnika rednega in izrednega študija. Razdelili smo 198 vprašalnikov, vrnjenih je bilo 196, kar je predstavljalo $99 \%$ odziv. Povprečna starost anketirancev je bila 21,23 let (starost med 19 in 42 let). Sodelovalo je 196 študentov, od tega jih je bilo $22(11,2 \%)$ moškega spola in $174(88,8 \%)$ ženskega spola. Med sodelujočimi je bilo $146(74,5 \%)$ študentov rednega in $47(25,5 \%)$ izrednega študija, trije sodelujoči načina študija niso označili. 18 (9,3\%) anketiranih je že zaposlenih v zdravstvu, medtem ko $176(90,7 \%)$ anketiranih ni zaposlenih $\mathrm{v}$ zdravstvu, dva anketiranca zaposlitve $\mathrm{v}$ zdravstvu nista potrdila oz. zanikala.

\section{Opis poteka raziskave in obdelave podatkov}

Pred izvedbo raziskave smo pridobili pisni soglasji vodstva Univerze v Mariboru Fakultete za zdravstvene vede in Komisije za etična vprašanja $s$ področja zdravstvene nege Univerze $\mathrm{v}$ Mariboru Fakultete za zdravstvene vede (2510-4/2014). Na podlagi pridobljenih soglasij je raziskava potekala $v$ študijskem letu 2013/2014 in študijskem letu 2014/2015 pri učnih enotah Zdravstvena nega žensk z ginekologijo in porodništvom ter Obvladovanje bolnišničnih okužb. Anketirani so bili seznanjeni $\mathrm{z}$ namenom in cilji raziskave. Sodelovanje $\mathrm{v}$ raziskavi je bilo prostovoljno, zagotovljena je bila anonimnost, saj so podatki interpretirani le $\mathrm{v}$ sumarni obliki. Za obdelavo podatkov smo uporabili statistični računalniški program SPSS verzija 20.0 (SPSS, Chicago, IL, USA). Uporabili smo deskriptivno statistiko, t-test za ugotavljanje razlik med skupinama ter korelacijsko analizo za ugotavljanje povezave med proučevanima spremenljivkama. Statistično značilnost smo preverjali na ravni $5 \%$ tveganja $(p<0,05)$.

\section{Rezultati}

Iz Tabele 1 je razvidno, da so povprečne ocene vseh trditev visoke ( $\bar{x}>4$ od 5). Ugotovili smo, da je najnižjo oceno prejela trditev \cenariji problemov so upoštevali študentovo okolje in kulturo « $(\bar{X}=4,18$, $s=0,833)$, najvišjo oceno pa trditev $»$ Problemi so bili $\mathrm{v}$ jasni povezavi zbodočim poklicem « $(\bar{X}=4,69, s=0,573)$. Med kategorijami kakovosti problemov, obravnavanih $\mathrm{v}$ okviru problemskega učenja, je najvišjo oceno prejela kategorija "povezanost $\mathrm{z}$ bodočim poklicem $\mathrm{v}$ realističnem kontekstu« $(\bar{X}=4,60, s=0,511)$.

$\mathrm{V}$ nadaljevanju smo $\mathrm{s}$ t-testom ugotavljali oceno kakovosti obravnavanih problemov glede na način študija (redni/izredni) in ugotovili, da pri nobeni od proučevanih kategorij "spodbujanje razmišljanja in analize« $(t=-0,286, p=0,101)$, »spodbujanje samousmerjenega učenja" $(t=-0,721, p=0,472)$, "usmerjanje $\mathrm{k}$ študiju predvidene vsebine« $(t=$ $-0,604, p=0,546)$, »večanje zanimanja za učno enoto« $(t=-0,071, p=0,944)$, "povezanost $\mathrm{z}$ bodočim poklicem v realističnem kontekstu « $(t=-0,990$, $p=0,324)$ in "ustreznost stopnji predhodnega znanja« $(t=-0,742, p=0,191)$ ne prihaja do statistično pomembnih razlik glede na način študija.

$S$ t-testom smo ugotavljali še statistično značilne razlike glede na zaposlitev $\mathrm{v}$ zdravstvu, ter ugotovili, da prihaja do statistično pomembnih razlik $\mathrm{v}$ oceni kakovosti obravnavanih primerov $\mathrm{v}$ naslednjih treh kategorijah: "usmerjanje $\mathrm{k}$ študiju predvidene vsebine $(t=3,226, p=0,004)$, "povezanost $z$ bodočim poklicem v realističnem kontekstu« $(t=3,989, p<$ $0,001)$ in "ustreznost stopnji predhodnega znanja« $(t=2,978, p=0,017)$. Prav tako smo st-testom ugotovili statistično pomembno razliko $(t=2,573, p=0,017)$ $\mathrm{v}$ skupni oceni kakovosti obravnavanih problemov glede na to, ali so študenti zaposleni v zdravstvu ali ne. Hkrati smo z raziskavo želeli ugotoviti tudi, kakšna je lastna splošna ocena študentov o kakovosti problemov, obravnavanih $\mathrm{v}$ okviru problemskega učenja, in ugotovili, da je njihova splošna ocena prav tako visoka $(\bar{x}=4,39, s=0,569)$, kot je bila skupna ocena vseh trditev $(\bar{x}=4,38, s=0,569) \mathrm{v}$ okviru uporabljenega vprašalnika.

Nato smo s t-testom želeli ugotoviti še, ali prihaja do statistično pomembnih razlik $\mathrm{v}$ lastni splošni oceni študentov glede na spol, način študija ter zaposlenost $\mathrm{v}$ zdravstvu, ter $\mathrm{s}$ korelacijsko analizo preveriti povezanost med starostjo in oceno kakovosti obravnavanih primerov (Tabela 2). 
Tabela 1: Ocena kakovosti problemov, obravnavanih v okviru problemskega pristopa učenja Table 1: Quality assessment of problems discussed in the context of the problem-based learning

\begin{tabular}{|c|c|c|}
\hline $\begin{array}{l}\text { Trditve in kategorije kakovosti obravnavanih problemov/ } \\
\text { Statements and categories regarding the quality of problems used }\end{array}$ & $\bar{x}$ & $s$ \\
\hline Problemi so bili za razpravo dovolj jasni. & 4,34 & 0,809 \\
\hline Problemi so dali optimalne napotke za razpravo. & 4,28 & 0,801 \\
\hline Problemi so vsebovali primerne spodbudne namige za razpravo. & 4,28 & 0,783 \\
\hline Spodbujanje razmišljanja in analize & 4,30 & 0,708 \\
\hline Problemi so študente spodbujali k formulaciji lastnih vprašanj. & 4,36 & 0,754 \\
\hline Problemi so študente spodbujali k iskanju ustrezne literature. & 4,42 & 0,790 \\
\hline Problemi so študente spodbujali k produktivni razpravi. & 4,46 & 0,719 \\
\hline Spodbujanje samousmerjenega učenja & 4,41 & 0,658 \\
\hline Problemi so naslavljali cilje ene ali več učnih enot. & 4,31 & 0,763 \\
\hline Problemi so spodbujali interdisciplinarnost. & 4,35 & 0,787 \\
\hline Problemi so spodbujali posvetovanje $\mathrm{z}$ literaturo, povezano $\mathrm{z}$ učno enoto. & 4,33 & 0,776 \\
\hline Usmerjanje $k$ študiju predvidene vsebine & 4,33 & 0,669 \\
\hline Scenariji problemov so večali študentovo zanimanje za učno enoto. & 4,44 & 0,830 \\
\hline Scenariji problemov so upoštevali študentovo okolje in kulturo. & 4,18 & 0,833 \\
\hline Scenariji problemov so bili študentom privlačni. & 4,31 & 0,804 \\
\hline Večanje zanimanja za učno enoto & 4,31 & 0,726 \\
\hline Problemi so bili v jasni povezavi z bodočim poklicem. & 4,69 & 0,573 \\
\hline Osnovni znanstveni koncepti so bili predstavljeni v kontekstu kliničnih problemov. & 4,47 & 0,660 \\
\hline Problemi so se navezovali na pacienta in ne samo na bolezen. & 4,61 & 0,585 \\
\hline Povezanost $z$ bodočim poklicem $v$ realističnem kontekstu & 4,60 & 0,511 \\
\hline Problemi so bili prilagojeni predznanju študentov. & 4,20 & 0,853 \\
\hline Problemi so bili povezani z že predelano literaturo. & 4,21 & 0,850 \\
\hline $\begin{array}{l}\text { Pred uvedbo problemskega pristopa učenja so bili študenti delno seznanjeni z znanjem, potrebnim za } \\
\text { rešitev problemov. }\end{array}$ & 4,29 & 0,725 \\
\hline Ustreznost stopnji predhodnega znanja & 4,37 & 0,650 \\
\hline Splošna ocena kakovosti obravnavanih problemov & 4,39 & 0,569 \\
\hline
\end{tabular}

Legenda/Legend: $\bar{x}$ - povprečje/average; $s-$ standardni odklon/standard deviation

Tabela 2: Rezultati t-testa in korelacijske analize

Table 2: Results of the t-test and correlation analysis

\begin{tabular}{|c|c|c|c|c|}
\hline $\begin{array}{l}\text { Spremenljivke/ } \\
\text { Variables }\end{array}$ & $\begin{array}{l}\text { Število anketiranih/ } \\
\text { Number of respondents }\end{array}$ & $\begin{array}{l}\text { Delež anketiranih (\%)/ } \\
\text { Proportion of respondents (\%) }\end{array}$ & $\bar{x}$ & $p$ \\
\hline \multicolumn{5}{|l|}{ Spol } \\
\hline Moški & 22 & 11,2 & 4,40 & $0,354^{*}$ \\
\hline Ženske & 174 & 88,8 & 4,37 & \\
\hline \multicolumn{5}{|l|}{ Način študija } \\
\hline Redni & 146 & 74,5 & 4,33 & $0,558^{\star}$ \\
\hline Izredni & 47 & 25,5 & 4,50 & \\
\hline \multicolumn{5}{|l|}{ Zaposlenost zdravstvu } \\
\hline $\mathrm{Da}$ & 18 & 9,3 & 4,67 & $0,040^{*}$ \\
\hline $\mathrm{Ne}$ & 176 & 90,7 & 4,35 & \\
\hline \multicolumn{5}{|l|}{ Starost } \\
\hline Minimum & 19 & I & 4,17 & $0,002^{* *}$ \\
\hline Maksimum & 42 & I & 5,00 & \\
\hline Povprečna starost & 21,2 & I & I & I \\
\hline
\end{tabular}

Legenda/Legend: ${ }^{*}$ - uporaba t-testa/t-test use; ${ }^{*}$ - uporaba korelacijske analize/use of correlation analysis; $p$ - statistična značilnost pri 0,05 ali manj/statistically significant at 0.05 or less

Tudi pri splošni oceni študentov glede kakovosti problemov, obravnavanih $\mathrm{v}$ okviru problemskega učenja, smo ugotovili, da prihaja do statistično značilne razlike $(t=2,109, p=0,040) \mathrm{v}$ oceni le med študenti glede na zaposlenost ali nezaposlenost $\mathrm{v}$ zdravstvu. Nismo pa ugotovili statistično značilnih razlik v splošni 
oceni kakovosti obravnavanih problemov glede na spol $(t=0,236, p=0,354)$ in način študija $(t=-1,333, p=$ $0,558)$, zato prve zastavljene hipoteze nismo potrdili. V nadaljevanju smo ugotovili še, da prihaja do šibke, vendar statistično značilne povezanosti med starostjo študentov in splošno oceno kakovosti obravnavanih problemov $(r=0,190, p=0,002)$ in $s$ tem potrdili drugo zastavljeno hipotezo.

\section{Diskusija}

Povprečne ocene proučevanih kategorij problemskega učenja so visoke, kar nakazuje na uporabo kakovostno oblikovanih problemov $\mathrm{Z}$ jasno opredeljenimi raziskovalnimi vprašanji. Kljub relativno visokim ocenam izpostavimo, da so najvišje ocene prejele trditve $\mathrm{v}$ okviru kategorije "povezanost $\mathrm{z}$ bodočim poklicem v realističnem kontekstu«, najnižje ocene pa so prejele trditve v okviru kategorije »spodbujanje razmišljanja in analize«. Strinjamo se $\mathrm{z}$ nekaterimi avtorji (Schmidt, et al., 2007; Loyens, et al., 2012), da je treba pri oblikovanju problemov upoštevati vse faze reševanja, ter z Rogal in Snider (2008), ki navajata, da učenje na podlagi kakovostno oblikovanih problemov pomaga študentom razvijati kritično mišljenje za reševanje problemov v kliničnih okoljih in zapolnjuje vrzel med teorijo in prakso. Dokazana je pozitivna povezanost med kritičnim mišljenjem in reševanjem problemov (Choi, et al., 2014). Sposobnost kritičnega mišljenja je predpogoj za uspešno reševanje simuliranih problemov $\mathrm{v}$ času izobraževanja ter kasneje za varno in učinkovito klinično prakso (Hendricson, et al., 2006; Pitt, et al., 2015). Avtorji Tiwari s sodelavci (2006) in Yuan s sodelavci (2008) so ugotovili povišanje uporabe kritičnega mišljenja pri vsebinah, katerih študij po metodi problemskega učenja traja vsaj eno leto.

Različni avtorji (Ozturk, et al., 2008; Yuan, et al., 2008) ugotavljajo, da samousmerjeno učenje spodbuja kritično mišljenje, kar povečuje sposobnosti za ocenjevanje pacientovih potreb in načrtovanje aktivnosti zdravstvene nege. Kategorija »spodbujanje samousmerjenega učenja«, je druga najvišje ocenjena kategorija. V okviru te kategorije sta najvišje ocenjeni trditvi, ki se nanašata na spodbujanje študentov $\mathrm{k}$ iskanju ustrezne literature in produktivni razpravi. Chan (2008) in Azer (2009) izpostavljata, da mora učitelj zagotoviti učinkovito skupinsko dinamiko s spodbujanjem aktivnega vključevanja študentov ter samostojnim in sodelovalnim učenjem. Vloga učitelja pri problemskem učenju je spodbuditi razpravo ter oceniti napredek in obseg dela, ki ga je prispeval študent (Schmidt, et al., 2007; Loyens, et al., 2012). Raziskave (Chikotas, 2009; Shuler, 2012; Cheng, et al., 2014) so pokazale, da se informacije, pridobljene $\mathrm{z}$ učenjem na podlagi reševanja problemov, prav zaradi samoučenja ohranijo dlje, hkrati se razvijajo spretnosti, ki omogočajo hitro prilagajanje situacijam v kliničnem okolju. Lekalakala Mokgele (2010) izpostavi predvsem težave pri študentih prvega letnika, ki se s problemskim učenjem srečajo prvič.

Visoko je ocenjena tudi kategorija »usmerjanje $\mathrm{k}$ študiju predvidene vsebine«, s čimer študenti nakazujejo na prepoznavanje pomembnosti upoštevanja ciljev učne enote, spodbujanje interdisciplinarnosti ter spodbujanje posvetovanja z literaturo. Strinjamo se z Dillard in Siktberg (2009), ki navajata, da morajo visokošolski zavodi v današnjem hitro spreminjajočem se svetu izvajati številne spremembe za uspešno soočanje $\mathrm{z}$ izzivi prihodnosti ter upoštevati predvsem kakovost programa za vse bolj raznoliko populacijo študentov. Mnogi avtorji (Giddens \& Brady, 2007; Brandon \& All, 2010; Giddens, et al., 2012; Hardin \& Richardson, 2012) ugotavljajo, da večina prenovljenih učnih načrtov s področja zdravstvene nege vključuje sodobne metode poučevanja.

Pri kategoriji "večanje zanimanja za učno enoto" je bila najvišje ocenjena trditev, ki se nanaša na povečanje študentovega zanimanja, iz česar izhaja, da so uporabljeni problemi študentom predstavljali izziv. Çinar in sodelavci (2010) navajajo, da učinkovite strategije reševanja problemov temeljijo na znanju, ki se pričakuje od študentov zdravstvene nege. Rotgans in Schmidt (2014) pa poudarjata, da prav pomanjkanje znanja, izkušenj in razumevanja za reševanje problemov, obravnavanih $\mathrm{v}$ okviru problemskega učenja, povečujejo zanimanje za predmet.

$\mathrm{Z}$ analizo kategorije "povezanost $\mathrm{Z}$ bodočim poklicem v realističnem kontekstu « smo ugotovili, da so vse trditve v tej kategoriji visoko ocenjene. Tudi nekateri drugi avtorji (Otting \& Zwaal, 2006; Rotgans \& Schmidt, 2011; Loyens, et al., 2012) izpostavljajo, da morajo problemi temeljiti na realnih problemih in pojavih in biti zastavljeni tako, da je njihovo reševanje za študente zanimivo ter da nakazujejo jasno povezavo $\mathrm{z}$ učno enoto. Na pomen uporabe realnih problemov nakazuje tudi statistično pomembna razlika $\mathrm{v}$ oceni povezanosti problemov problemskega učenja $\mathrm{z}$ bodočim poklicem glede na zaposlitev oz. nezaposlitev v zdravstvu. Študenti, ki so v zdravstvu že zaposleni, ocenjujejo, da so za profesionalno znanje izkušnje pomembnejše kot način študija. Lekalakala Mokgele (2010) ugotavlja, da se študenti zdravstvene nege na problemsko učenje $\mathrm{v}$ malih skupinah odzivajo različno, odvisno od predhodnih metod poučevanja, izobrazbe in letnika študija. Tudi mi smo $\mathrm{v}$ raziskavi zaznali pozitivno šibko povezanost med starostjo in oceno kakovosti obravnavanih primerov.

Do statistično pomembnih razlik prihaja v kategoriji »ustreznost stopnji predhodnega znanja« le glede na zaposlitev študentov, kar nakazuje na pomembnost uporabe problemov, ki ustrezajo stopnji predznanja študentov. Smiselno bi bilo uvesti pripravljalne delavnice $\mathrm{v}$ okviru učnega načrta, kjer bi učitelji dobili boljši vpogled $\mathrm{v}$ študentovo predznanje o učnih vsebinah in metodi problemskega učenja.

Omejitev raziskave vidimo v tem, da je bila raziskava 
izvedena na priložnostnem vzorcu v eni izobraževalni instituciji in le pri dveh predmetih, zato rezultatov ne moremo posploševati. Vzorec ni reprezentativen, saj $\mathrm{v}$ raziskavo niso bili vključeni študenti vseh letnikov visokošolskega študijskega programa zdravstvene nege, prav tako $\mathrm{v}$ raziskavo niso bile vključene učne enote, kjer problemsko učenje ni del učnega načrta. Kljub temu rezultati kažejo na potrebo po nadaljnjem raziskovanju zaradi spremljanja vpliva problemskega učenja na učne izide ter na potrebo po uvedbi problemskega učenja $\mathrm{v}$ vse učne enote.

\section{Zaključek}

Študenti zdravstvene nege kakovost problemov, obravnavanih pri problemskem učenju, ocenjujejo zelo visoko. Ta metoda učenja poleg učenja dejstev pri študentih spodbuja samousmerjeno učenje, povečuje zanimanje za učno enoto, izboljšuje motivacijo za delo, komunikacijske spretnosti in kritično razmišljanje. Prav kritično razmišljanje pa je spretnost, ki je predpogoj za uspešno reševanje simuliranih problemov. Za uspešno problemsko učenje so ključnega pomena visoko kakovostno oblikovani problemi $\mathrm{z}$ elementi odprtosti, privlačnosti, razumljivosti in ustreznosti ravni predznanja študentov. V raziskavi ugotavljamo, da imajo študenti brez izkušenj $\mathrm{v}$ zdravstvu zaradi pomanjkanja predhodnega znanja včasih težave pri reševanju problemov problemskega učenja. Tako je nujno, da pri pripravi in oblikovanju problemov problemskega učenja načrtujemo stopnjo oz. težavnost problema, ki se ujema s predhodnim znanjem in delovnimi izkušnjami študentov. Pri tem uporabimo strategije učenja s ciljem zmanjšati razkorak med teoretičnimi koncepti in prakso zdravstvene nege ter preiti od tradicionalnih $\mathrm{k}$ aktivnim oblikam poučevanja.

\section{Literatura}

Al Kloub, M.I., Salameh, T.N. \& Froelicher, E.S., 2014. Nursing students evaluation of problem based learning and the impact of culture on the learning process and outcomes: a pilot project. Nurse Education in Practice, 14(2), pp. 142-147. http://dx.doi.org/10.1016/j.nepr.2013.06.013 PMid:23871300

AlHaqwi, A.I., 2014. Learning outcomes and tutoring in problem-based learning: how do undergraduate medical students perceive them? International Journal of Health Sciences, 8(2), pp. 125-132.

http://dx.doi.org/10.12816/0006078

PMid:25246879; PMCid:PMC4166984

Azer, S.A., 2007. Twelve tips for creating trigger images for problembased learning cases. Medical Teacher, 29(2-3), pp. 93-97. http://dx.doi.org/10.1080/01421590701291444

PMid:17701617
Azer, S.A., 2009. Interactions between students and tutors in problem based learning: the significance of deep learning. The Kaohsiung Journal of Medical Sciences, 25(5), pp. 240-249.

http://dx.doi.org/10.1016/S1607-551X(09)70068-3

PMid:19502144

Azizi-Fini, I., Hajibagheri, A. \& Adib-Hajbaghery, M., 2015. Critical thinking skills in nursing students: a comparison between freshmen and senior students. Nursing and Midwifery Studies, 4(1), p. e25721.

http://dx.doi.org/10.17795/nmsjournal25721

PMid:25830160; PMCid:PMC4377532

Borglin, G., 2012. Promoting critical thinking and academic writing skills in nurse education. Nurse Education Today, 32(5), pp. 611-613.

http://dx.doi.org/10.1016/j.nedt.2011.06.009

PMid:21807442

Brandon, A.F. \& All, A.C., 2010. Constructivism theory analysis and application to curricula. Nursing Education Perspectives, 31(2), pp. 89-92.

PMid:20455364

Chan,L.C., 2008. TheroleofaPBLtutor: apersonal perspective. The Kaohsiung Journal of Medical Sciences, 24(Suppl 3), pp: S34-S38. http://dx.doi.org/10.1016/S1607-551X(08)70092-5

Cheng, C.Y., Liou, S.R., Tsai, H.M. \& Chang, C.H., 2014. The effects of team-based learning on learning behaviors in the maternal-child nursing course. Nurse Education Today, 34(1), pp. 25-30.

http://dx.doi.org/10.1016/j.nedt.2013.03.013

PMid:23618848

Chikotas, N.E., 2009. Problem-based learning and clinical practice: the nurse practitioners' perspective. Nurse Education in Practice, 9(6), pp. 393-397.

http://dx.doi.org/10.1016/j.nepr.2009.01.010

PMid:19233724

Choi, E., Lindquist, R. \& Song, Y., 2014. Effects of problembased learning vs. traditional lecture on Korean nursing students critical thinking, problem-solving, and self-directed learning. Nurse Education Today, 34(1), pp. 52-56.

http://dx.doi.org/10.1016/j.nedt.2013.02.012

PMid:23535270

Çinar, N., Sözeri, C., Şahin, S., Cevahir, R. \& Say, M., 2010. Problem solving skills of the nursing and midwifery students and influential factors. Revista Eletrônica de Enfermagem, 12(4), pp. 601-606.

http://dx.doi.org/10.5216/ree.v12i4.8328

Dillard, N. \& Siktberg, L., 2009. Curriculum development: an overview. In: Billings, D.M. \& Halstead, J.A. eds. Teaching in nursing: a guide for faculty. 3rd ed. St. Louis: Saunders Elsevier, pp. 75-91. 
Giddens, J.F. \& Brady, D.P., 2007. Rescuing nursing education from content saturation: the case for a concept-based curriculum. Journal of Nursing Education, 46(2), pp. 65-69. PMid:17315564

Giddens, J.F., Wright, M. \& Gray, I., 2012. Selecting concepts for a concept-based curriculum: application of a benchmark approach. Journal of Nursing Education, 51(9), pp. 511-515. http://dx.doi.org/10.3928/01484834-20120730-02 PMid:22849765

Hardin, P.K. \& Richardson, S.J., 2012. Teaching the concept curricula: theory and method. Journal of Nursing Education, 51(3), pp. 155-159.

http://dx.doi.org/10.3928/01484834-20120127-01

PMid:22283151

Hendricson, W.D., Andrieu, S.C., Chadwick, G., Chmar, J.E., Cole, J.R., George, M.C., et al., 2006. Educational strategies associated with development of problem-solving, critical thinking, and self-directed learning. Journal of Dental Education, 70(9), pp. 925-936.

PMid:16954414

Hmelo Silver, C.E. \& Barrows, H., 2006. Goals and strategies of a problem-based learning facilitator. Interdisciplinary Journal of Problem-Based Learning, 1(1), pp. 21-39.

http://dx.doi.org/10.7771/1541-5015.1004

Hmelo Silver, C.E. \& Barrows, H.S., 2008. Facilitating collaborative knowledge building. Cognition and Instruction, 26(1), pp. 48-94. http://dx.doi.org/10.1080/07370000701798495

Hmelo Silver, C.E. \& Barrows, H.S., 2015. Problem-based learning: goals for learning and strategies for facilitating. In: Walker, A., Leary, H., Hmelo Silver, C.E. \& Ertmer A. eds. Essential readings in problem-based learning. West Lafayete, Indiana: Purdue University press.

Hmelo Silver, C.E. \& Eberbach, C., 2012. Learning theories and problem-based learning. In: Bridges, S., McGrath, C. \& Whitehill, T. eds. Problem-based learning in clinical education: the next generation. New York: Springer, pp. 3-17. http://dx.doi.org/10.1007/978-94-007-2515-7 1

Hwang, S.Y. \& Kim, M.J., 2006. A comparison of problem-based learning and lecture-based learning in an adult health nursing course. Nurse Education Today, 26(4), pp. 315-321.

http://dx.doi.org/10.1016/j.nedt.2005.11.002

PMid:16364510

Jones, M., 2008. Developing clinically savvy nursing students: an evaluation of problem-based learning in an associate degree program. Nursing Education Perspectives, 29(5), pp. 278-283. PMid:18834057
Kapur, M. \& Kinzer, C.K., 2007. Examining the effect of problem type in a synchronous computer-supported collaborative learning (CSCL) environment. Educational Technology Research and Development, 55(5), pp. 439-459.

http://dx.doi.org/10.1007/s11423-007-9045-6

Kim, S., Phillips, W.R., Pinsky, L., Brock, D., Phillips, K. \& Keary, J., 2006. A conceptual framework for developing teaching cases: a review and synthesis of the literature across disciplines. Medical Education, 40(9), pp. 867-876.

http://dx.doi.org/10.1111/j.1365-2929.2006.02544.x

PMid:16925637

Kong, L.N., Qin, B., Zhou, Y., Mou, S. \& Gao, H.M., 2014. The effectiveness of problem-based learning on development of nursing students' critical thinking: a systematic review and meta-analysis. International Journal of Nursing Studies, 51(3), pp. $458-469$.

http://dx.doi.org/10.1016/j.ijnurstu.2013.06.009

PMid:23850065

Lekalakala Mokgele, E., 2010. Facilitation in problem-based learning: experiencing the locus of control. Nurse Education Today, 30(7), pp. 638-642.

http://dx.doi.org/10.1016/j.nedt.2009.12.017

PMid:20089334

Loyens, S.M.M., 2014. New approaches to problem-based learning: revitalizing your practice in higher education. Interdisciplinary Journal of Problem-Based Learning, 8(1), pp. 85-87.

http://dx.doi.org/10.7771/1541-5015.1519

Loyens, S.M.M., Kirschner, P. \& Paas, F., 2012. Problem-based learning. In: Graham, S., Bus, A., Major, S. \& Swanson, L. eds. APA educational psychology handbook, application to learning and teaching. Vol. 3. Washington: American Psychological Association, pp. 403-425.

http://dx.doi.org/10.1037/13275-016

Lu, J., Lajoie, S.P. \& Wiseman, J., 2010. Scaffolding problembased learning with CSCL tools. International Journal of Computer Supported Collaborative Learning, 5(3), pp. 283-298. http://dx.doi.org/10.1007/s11412-010-9092-6

Martyn, J., Terwijn, R., Kek, M.Y. \& Huijser, H., 2014. Exploring the relationships between teaching, approaches to learning and critical thinking in a problem-based learning foundation nursing course. Nurse Education Today, 34(5), pp. 829-835.

http://dx.doi.org/10.1016/j.nedt.2013.04.023 PMid:23706962

Munshi, F.M., El Zayat, E.S.A. \& Dolmans, D.H., 2008. Development and utility of a questionnaire to evaluate the quality of PBL problems. South East Asian Journal of Medical Education, 2(2), pp. 32-40. 
Niemer, L., Pfendt, K. \& Gers, M., 2010. Problem-based learning in nursing education: a process for scenario development. Nurse Educator, 35(2), pp. 69-73.

http://dx.doi.org/10.1097/NNE.0b013e3181ced891

PMid:20173591

Otting, H. \& Zwaal, R., 2006. Critical task characteristics in problem-based learning. Industry \& Higher Education, 20(5), pp. 347-357.

http://dx.doi.org/10.5367/000000006778702283

Ozturk, C., Muslu, G.K. \& Dicle, A., 2008. A comparison of problem-based and traditional education on nursing students' critical thinking. Nurse Education Today, 28(5), pp. 627-632. http://dx.doi.org/10.1016/j.nedt.2007.10.001

PMid:18054412

Paul, S.A., 2012. Assessment of critical thinking: a Delphi study. Nurse Education Today, 34(11), pp. 1357-1360.

http://dx.doi.org/10.1016/j.nedt.2014.03.008

PMid:24713126

Pitt, V., Powis, D., Levett Jones, T. \& Hunter, S., 2015. The influence of critical thinking skills on performance and progression in a pre-registration nursing program. Nurse Education Today, 35(1), pp. 125-131.

http://dx.doi.org/10.1016/j.nedt.2014.08.006

PMid:25194469

Rogal, S.M. \& Snider, P.D., 2008. Rethinking the lecture: the application of problem based learning methods to atypical contexts. Nurse Education in Practice, 8(3), pp. 213-219.

http://dx.doi.org/10.1016/j.nepr.2007.09.001

PMid:17950670

Rotgans, J.I. \& Schmidt, H.G., 2011. Situational interest and academic achievement in the active-learning classroom. Learning and Instruction, 21(1), pp. 58-67.

http://dx.doi.org/10.1016/j.learninstruc.2009.11.001

Rotgans, J.I. \& Schmidt, H.G., 2014. Situational interest and learning: thirst for knowledge. Learning and Instruction, 32, pp. 37-50.

http://dx.doi.org/10.1016/j.learninstruc.2014.01.002

Sangestani, G. \& Mahnaz, K., 2013. Comparison of problembased learning and lecture-based learning in midwifery. Nurse Education Today, 33(8), pp. 791-795.

http://dx.doi.org/10.1016/j.nedt.2012.03.010

PMid:22503681
Schmidt, H.G., Loyens, S.M.M., van Gog, T. \& Paas, F., 2007. Problem-based learning is compatible with human cognitive architecture: commentary on Kirschner, Sweller, and Clark (2006). Educational Psychologist, 42(2), pp. 91-97. http://dx.doi.org/10.1080/00461520701263350

Schmidt, H.G., van der Molen, H.T., te Winkel, W.W.R. \& Wijnen, W.H.F.W., 2009. Constructivist, problem-based learning does work: a meta-analysis of curricular comparisons involving a single medical school. Educational Psychologist, 44(4), pp. 227-249.

http://dx.doi.org/10.1080/00461520903213592

Shuler, C.F., 2012. Comparisons in basic science learning outcomes between students in PBL and traditional dental curricula at the same dental school. In: Bridges, S., Colman McGrath, T. \& Whitehill, L. eds. Problem-based learning in clinical education: the next generation. New York: Springer, pp. 35-46.

http://dx.doi.org/10.1007/978-94-007-2515-7 3

Thammasitboon, K., Sukotjo, C., Howell, H. \& Karimbux, N., 2007. Problem-based learning at the Harvard school of dental medicine: self-assessment of performance in postdoctoral training. Journal of Dental Education, 71(8), pp. 1080-1089. PMid:17687090

Tiwari, A., Ali, P., So, M. \& Yuen, K., 2006. A comparison of the effects of problem-based learning and lecturing on the development of students' critical thinking. Medical Education, 40(6), pp. 547-554.

http://dx.doi.org/10.1111/j.1365-2929.2006.02481.x PMid:16700770

Walker, A.E. \& Leary, H., 2009. A problem based learning meta analysis: differences across problem types, implementation types, disciplines, and assessment levels. Interdisciplinary Journal of Problem-Based Learning, 3(1), pp. 12-43.

http://dx.doi.org/10.7771/1541-5015.1061

Yuan, H., Williams, B.A. \& Fan, L., 2008. A systematic review of selected evidence on developing nursing students' critical thinking through problem-based learning. Nurse Education Today, 28(6), pp. 657-663.

http://dx.doi.org/10.1016/j.nedt.2007.12.006

PMid:18267348

Citirajte kot/Cite as:

Gönc, V., Lorber, M. \& Nerat J., 2016. Kakovost problemov, obravnavanih pri problemskem učenju: ocena študentov zdravstvene nege. Obzornik zdravstvene nege, 50(3), pp. 207-214. http://dx.doi.org/10.14528/snr.2016.50.3.113 